\title{
ANALISIS PEMETAAN JUMLAH KONSUMSI DAN PENGADAAN BERAS DI WILAYAH KECAMATAN KABUPATEN JOMBANG
}

\author{
Sumarsono $^{1}$, Minto $^{2}$, Totok Yulianto ${ }^{3}$, Sulung Rahmawan Wira Ghani ${ }^{4}$ \\ ${ }^{1}$ Fakultas Teknik Universitas Hasyim Asy'ari \\ ${ }^{1}$ sonsumarsono13@gmail.com
}

\begin{abstract}
Referring to the 2012 to 2016 data trends, it is seen that there is an inconsistency between the levels of rice productivity with the population growth rate in Jombang. This illustrates the level of demand for consumption continuing to increase. Rice productivity is relatively stable while demand for rice consumption continues to grow. Thus, this research aimed to analyze the mapping of rice consumption amount and procurement variables in Jombang sub-districts, as an evaluation material, prevention and handling the imbalance between rice consumption growth and procurement. The quantitative method with biplot analysis was used. The data was collected from the publication data of district agriculture department and BPS of Jombang in 2012 - 2016. The research results show that the diversity mapping of consumption and procurement variables in rice was relatively the same. This means that the uniformity between consumption and rice procurement variables from 21 sub-districts in Jombang is relatively the same. Furthermore, the relationship between consumption with rice procurement is close, so the amount of rice consumption having been formed has no close relationship with the amount of rice procurement. Then, there were 6 groups of sub-districts having similarities related to rice consumption and procurement variables. The grouping results provide a reference to the target of more appropriate handling for each sub-district group. Next, there were sub-districts exceling above, around and below the average related to rice consumption and procurement variables. These provide an overview of the priority scale that can be adjusted to the rice availability program.
\end{abstract}

Keywords: Biplot analysis, Rice consumptions, Rice procurements

\begin{abstract}
Abstrak: Mengacu tren data tahun 2012 sampai 2016 terkait produktifitas beras dan pertumbuhan penduduk, terlihat ada ketidakselarasan antara tingkat produktifitas beras dengan tingkat pertumbuhan penduduk di kabupaten Jombang, ini menggambarkan tingkat konsumsi yang terus meningkat. Produktifitas beras yang relatif stabil sedangkan konsumsi beras yang terus bertambah, merupakan masalah terkait ketersediaan beras. Berdasarkan situasi tersebut, artikel bertujuan menganalisis pemetaan variabel jumlah konsumsi dan pengadaan beras diwilayah kecamatan kabupaten Jombang, sebagai bahan evaluasi, pencegahan, penanganan ketidakseimbangan antara pertumbuhan konsumsi dan pengadaan beras. Metode penelitian menggunakan metode kuantitatif analisis biplot. Data penelitian bersumber dari data publikasi departemen pertanian kabupaten Jombang, BPS Jombang, dengan periode tahun 2010 sampai 2016. Variabel penelitian yakni jumlah konsumsi dan pengadaan beras dalam satuan kwintal per tahun per kecamatan. Hasil analisis biplot disimpulkan: Pemetaan keragaman variabel konsumsi dan pengadaan beras adalah relatif sama, yang berarti kebutuhan antara variabel konsumsi dengan pengadaan beras dari 21 kecamatan di kabupaten Jombang relatif seragam. Selanjutnya hasil pemetaan korelasi, variabel konsumsi dengan pengadaan beras di wilayah kecamatan kabupaten Jombang memiliki hubungan yang tidak erat, sehingga disimpulkan jumlah konsumsi beras yang terbentuk, tidak memiliki keterkaitan erat dengan jumlah pengadaan beras. Hasil pemetaan kemiripan karakteristik antar kecamatan, terdapat 6 kelompok kecamatan yang memiliki kesamaan variabel konsumsi dengan pengadaan beras. Hasil pengelompokan ini memberi acuan kepada target penanganan yang lebih tepat untuk setiap kelompok kecamatan. Hasil pemetaan posisi keunggulan kecamatan, terdapat kelompok kecamatan yang unggul diatas rata-rata, disekitar rata-rata, dan dibawah rata-rata. Hal ini memberikan gambaran skala prioritas yang bisa disesuaikan dengan program ketersediaan pangan beras.

Kata kunci: Analisis biplot, Konsumsi beras, Pengadaan beras
\end{abstract}




\section{Pendahuluan}

Produk pangan beras tergolong dalam komoditas subsistem karena beras dikonsumsi sendiri oleh keluarga petani dan sisanya dijual ke pasar (Afrianto: 2010). Pangan beras merupakan makanan utama masyarakat Indonesia. Berdasarkan penelitian Lastinawati (2010) bahwa ketergantungan pada satu jenis komoditas pangan yakni beras adalah salah satu masalah dalam ketahanan pangan. Hal ini dimungkinkan dari sisi pengadaan produksi beras yang bisa mengalami hambatan dikarenakan sebab seperti ketersediaan air irigasi yang harus cukup, adanya pengubahan lahan sawah ke non sawah untuk perumahan, jalan, fasilitas umum dll. Sedangkan disisi lain usaha atau program memperluas lahan sawah memiliki biaya yang mahal dan bahkan tidak dilakukan karena secara aspek teknis, sosial dan ekonomi mensyaratkan lahan yang layak untuk dijadikan lahan sawah semakin tidak ada.

Arsyad (2018) menyatakan harga pangan, pertumbuhan penduduk, konversi lahan pertanian ke non-pertanian, konsumsi pangan dari waktu ke waktu akan mengalami kecenderungan naik. Lebih lanjut krisis akan pangan di Indonesia bukan karena stok terbatas akan tetapi lebih karena keterbatasan akses ke pangan. Sehingga usaha-usaha menciptakan ketersediaan (pengadaan) pangan adalah sangat diperlukan untuk menciptakan ketahanan pangan.

Sementara itu disisi permintaan konsumsi beras dari tahun ke tahun diketahui trendnya mengalami peningkatan. Menurut BKKBN di tahun 2018 bahwa 262 juta penduduk Indonesia memerlukan beras sekitar lebih dari 30 juta ton setahun untuk kebutuhan industri dan rumah tangga. Kemudian kebutuhan akan beras tersebut akan mengalami peningkatan terus sesuai pertumbuhan jumlah penduduk. Apabila pertumbuhan penduduk rata-rata $1,49 \%$ setahun, maka ada pertambahan 4 juta jiwa setiap tahunnya.
Sebagai bahan pangan pokok, isu masalah ketahanan pangan beras di Indonesia terjadi di semua wilayah, tidak terkecuali di wilayah kabupaten Jombang propinsi Jawa Timur. Diketahui jumlah penduduk berdasarkan data BPS-Jombang di tahun 2016 sebanyak 1,25 juta jiwa. Selanjutnya berdasarkan data penduduk dari tahun 2012 sampai tahun 2016 diketahui trend pertumbuhan yang tajam, dengan ratarata penambahan sekitar 6390 jiwa per tahun. Hal ini berdampak kepada permintaan jumlah konsumsi beras yang terus meningkat.

Sedangkan disisi lain jumlah pengadaan produksi padi di kabupaten Jombang pada periode tahun yang sama yakni 2012 sampai 2016 diketahui trendnya fluktuatif naik-turun. Hasil perkiraan pertambahan pertahunnya sekitar 29.500 kwintal padi. Kemudian apabila dikonversi menjadi beras yakni $62 \%$ nya, yakni 18.290 kwintal beras. Menurut Kementerian Pertanian (2016) bahwa tingkat konsumsi beras rata-rata masyarakat Indonesia sebesar $130 \mathrm{~kg} / \mathrm{kapita} / \mathrm{th}$. Apabila pertumbuhan penduduk kabupaten Jombang pertahun nya sekitar 6.390 jiwa maka dibutuhkan penambahan jumlah beras sekitar 830.700 $\mathrm{Kg}$ atau $8.307 \mathrm{kwintal}$ untuk konsumsi akhir (rumah tangga). Sehingga dapat diartikan selama ada pertambahan pertambahan penduduk maka jumlah konsumsi beras oleh rumah tangga akan terus meningkat, dan tentunya juga konsumsi beras oleh industri.

Berdasarkan uraian diatas, terlihat adanya ketidakselarasan antara tingkat produktifitas beras dengan tingkat pertumbuhan penduduk di kabupaten Jombang, ini menggambarkan tingkat permintaan akan konsumsi yang terus meningkat. Produktifitas beras yang relatif stabil sedangkan permintaan konsumsi beras yang terus bertambah, merupakan masalah terkait ketersediaan beras. Menurut Badan Ketahanan Pangan (2018) bahwa ketersediaan (pengadaan), dan konsumsi akan beras merupakan sub sistem yang terintegrasi terkait ketahanan pangan beras 
disuatu wilayah. Sehingga pada artikel ini peneliti bertujuan menganalisis pemetaan variabel konsumsi dan pengadaan beras diwilayah kecamatan kabupaten Jombang, sebagai bahan evaluasi, masukan pencegahan, penanganan ketidakseimbangan antara pertumbuhan konsumsi dan pengadaan beras.

\section{Metode}

Desain penelitian ini menggunakan pendekatan kuantitatif analitik dengan melakukan analisa data untuk kemudian mendapatkan hasil analisa. Metode analisa menggunakan analisis biplot untuk menganalisis pemetaan variabel penelitian yang ditinjau dari obyek penelitian. Obyek penelitian yakni 21 kecamatan di kabupaten Jombang. Variabel penelitian meliputi jumlah konsumsi dan pengadaan beras. Berikut kerangka analisis dari penelitian ini.

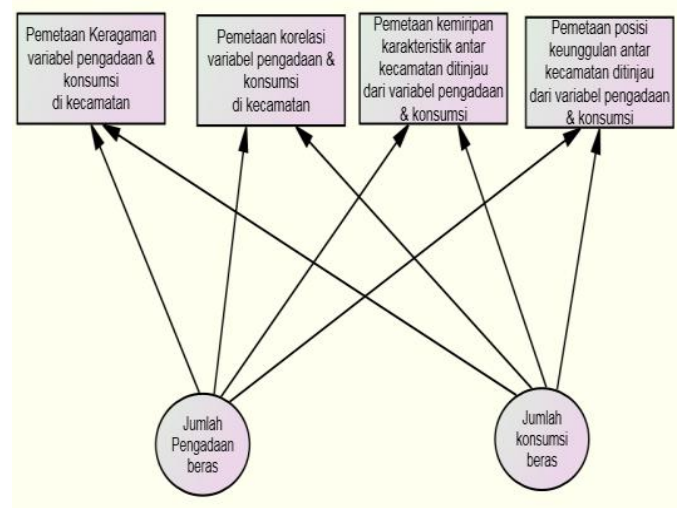

Gambar 1. Kerangka Analisis Penelitian

Data penelitian bersumber dari data sekunder yakni data publikasi departemen pertanian kabupaten Jombang, data BPS Jombang dalam angka 2017. Metode analisis data menggunakan analisa Biplot, menurut Mattjik, dkk (2011) bahwa analisis Biplot merupakan teknik statistik yang menyajikan secara visual dari $n$ obyek dan $\mathrm{p}$ variabel dalam 2 dimensi, sehingga ciri-ciri variabel dan obyek pengamatan serta posisi relatif antara obyek pengamatan dengan variabel dapat dianalisis.

Selanjutnya menurut Siswanto, dkk (2016) proses analisis yang dilakukan dalam analisis biplot yakni:
(1) Menentukan eigenvalue dan skor faktor dari variabel serta obyek penelitian, dengan menggunakan principle component analysis (PCA). Nilai eigen bertujuan mengetahui tingkat keragaman dari hasil biplot yang didapat. Kemudian skor faktor akan digunakan membuat plot gambar dari variabel dan obyek penelitian.

(2) Membuat plot gambar biplot, berdasarkan nilai skor faktor dari variabel dan obyek penelitian.

(3) Selanjutnya melakukan analisis dari hasil biplot, yakni meliputi analisis pemetaan.

Informasi hasil analisis pemetaan dari biplot akan didapatkan 4 informasi (Rukini: 2017), yakni:

a. Analisis pemetaan keragaman dari variabel jumlah konsumsi dan jumlah pengadaan beras, yang tergambar dari panjang-pendeknya vektor, yakni garis sepenajang variabel dari titik pusat $(0,0)$. Keragaman yang tinggi dari suatu variabel tergambar dengan vektor yang lebih panjang, sebaliknya vektor yang lebih pendek mengartikan memiliki keragamanan yang lebih kecil.

b. Analisis pemetaan keeratan korelasi hubungan antara variabel, apabila dua vektor variabel membentuk sudut sempit $\left(<90^{\circ}\right)$ maka diartikan hubungan dua variabel tersebut memiliki korelasi erat dengan arah hubungan yang positif. Sedangkan hubungan korelasi dengan arah hubungan negatif tergambar dari dua vektor variabel membentuk sudut lebar $\left(>90^{\circ}\right)$. Kemudian dua variabel tidak memiliki hubungan yang erat, tergambarkan dengan dua vektor garis yang membentuk sudut mendekati $90^{\circ}$.

c. Analisis pemetaan kemiripan karakteristik dari obyek penelitian, yang tergambar dari titik-titik koordinat obyek yang berdekatan posisinya. Obyek penelitian dengan titik-titik koordinat yang berdekatan, 
memberi gambaran adanya kemiripan karakteristik dan sebaliknya obyek dengan titik koordinat berjauhan, memberikan gambaran tidak adanya kemiripan karakteristik. Sehingga dengan analisis ini dapat digunakan untuk pengelompokan wilayah kecamatan.

d. Analisis pemetaan posisi keunggulan antara obyek penelitian, suatu obyek penelitian bernilai diatas rata-rata apabila posisi obyek terletak searah dengan arah vektor variabel. Sedangkan apabila posisi obyek terletak berlawanan arah dengan arah vektor variabel, maka diartikan memiliki nilai dibawah rata-rata. Kemudian jika posisi obyek hampir berada ditengah-tengah maka obyek tersebut memiliki nilai yang dekat dengan rata-rata.

\section{Hasil dan Pembahasan}

\section{Analisis Deskriptif}

Hasil penelitian pertama diketahui dari analisis deskripsi yang menggambarkan sekilas dari variabel yang diteliti dengan bantuan aplikasi software SPSS. Alat deskriptif yang digunakan dengan menggunakan nilai pemusatan data yakni nilai rata-rata, dan kemudian nilai penyebaran data dengan menggunakan nilai range (minimum dan maksimum) serta standart deviasi (Ghozali, 2018). Variabel dalam penelitian ini yakni pengadaan beras, dan jumlah konsumsi beras di wilayah kecamatan-kecamatan kabupaten Jombang, selama tahun 2010 sampai 2016 yang diratarata. Hasil deskriptif selengkapnya sebagai berikut.

(1) Pengadaan Beras

Variabel pengadaan beras merupakan jumlah beras yang tersimpan dalam suatu daerah setiap tahunnya. Pengadaan beras yang diukur yakni jumlah beras yang tersimpan di setiap kecamatan dari kabupaten Jombang. Dengan satuan pengukuran dalam kwintal per tahun. Berdasarkan data pengadaan beras tahun
2010 sampai dengan 2016, rata-rata sebanyak 134.554 kwintal pertahun dengan nilai simpangan baku nya sebesar 58.449 kwintal per hektar. Nilai tersebut mengartikan bahwa jumlah pengadan beras terpusat pada nilai 134.554 kwintal per tahun per kecamatan, dengan penyebaran nilai disekitar rata-rata sebesar 58.449 kwintal per tahun. Selanjutmya rentang jumlah pengadaan beras yakni paling minimum sebanyak 19.112 dan maksimum sebanyak 277.924 kwintal per tahun. Berikut selengkapnya tabel jumlah pengadaan beras selama 7 tahun yakni dari 2010 sampai 2016.

Tabel 1. Jumlah Pengadaan Beras Kabupaten Jombang Tahun 2010-2016

\begin{tabular}{|c|c|c|c|c|}
\hline Tahun & $\begin{array}{c}\text { Rata- } \\
\text { rata }\end{array}$ & Min & Max & $\begin{array}{c}\text { Simpang } \\
\text { an baku }\end{array}$ \\
\hline 2010 & 141.447 & 41.102 & 277.924 & 63.012 \\
\hline 2011 & 116.089 & 31.775 & 230.169 & 49.332 \\
\hline 2012 & 141.036 & 34.147 & 267.465 & 62.709 \\
\hline 2013 & 131.751 & 31.790 & 242.263 & 59.550 \\
\hline 2014 & 131.448 & 31.068 & 256.848 & 56.746 \\
\hline 2015 & 137.384 & 19.112 & 273.347 & 58.785 \\
\hline 2016 & 142.720 & 24.632 & 258.828 & 61.901 \\
\hline Rerata & 134.554 & 19.112 & 277.924 & 58.449 \\
\hline
\end{tabular}

Sumber: Hasil analisa deskriptif (2020)

(2) Konsumsi beras

Variabel konsumsi beras merupakan jumlah konsumsi terhadap beras suatu wilayah dalam hal ini kecamatan selama setahun. Jumlah konsumsi beras yang diukur yakni setiap kecamatan di kabupaten Jombang dengan satuan kwintal per tahun.

Berdasarkan data tahun 2010 sampai 2016, bahwa rata-rata jumlah konsumsi sebesar 52.487 kwintal per tahun dengan simpangan baku nya sebesar 24.641 kwintal. Hal tersebut memberi arti bahwa jumlah konsumsi beras di kecamatan memusat disekitar nilai 52.487 kwintal per tahun dengan simpangan disekitar rata-rata sebesar 24.641 kwintal. Lebih lanjut diketahui rentang penyebaran jumlah konsumsi beras minimal 18.744 dan jumlah 
maksimal 130.606 kwintal setahun, untuk selengkapnya disampaikan pada tabel berikut ini.

Tabel 2. Jumlah konsumsi beras kabupaten Jombang tahun 2010-2016

\begin{tabular}{|c|c|c|c|c|}
\hline Tahun & $\begin{array}{c}\text { Rata- } \\
\text { rata }\end{array}$ & Min & Max & $\begin{array}{c}\text { Simpangan } \\
\text { baku }\end{array}$ \\
\hline 2010 & 51.292 & 18.744 & 122.970 & 24.399 \\
\hline 2011 & 53.334 & 19.145 & 130.606 & 26.149 \\
\hline 2012 & 51.943 & 18.887 & 125.291 & 24.923 \\
\hline 2013 & 52.389 & 19.000 & 126.749 & 25.246 \\
\hline 2014 & 52.543 & 19.008 & 127.513 & 25.430 \\
\hline 2015 & 52.819 & 19.058 & 128.571 & 25.674 \\
\hline 2016 & 53.088 & 19.232 & 114.466 & 24.202 \\
\hline Rerata & 52.487 & 18.744 & 130.606 & 24.641 \\
\hline
\end{tabular}

Sumber: Hasil analisa deskriptif (2020)

(3) Pengadaan versus konsumsi beras

Variabel pengadaan dan konsumsi beras merupakan dua variabel yang saling berlawanan, perbandingan kedua variabel tersebut merupakan suatu nilai rasio ketersedian beras. Selanjutnya rasio kesetersedian beras ini merupakan indikator dari ketahanan pangan beras. Deskripsi dari variabel pengadaan dan konsumsi beras pada setiap kecamatan di kabupaten Jombang, akan memberikan gambaran ketersediaan beras disetiap wilayah kecamatan, dan menjadi sinyal awal akan ketahanan pangan beras diwilayah kecamatan.

Berdasarkan data rata-rata tahun 2010 sampai 2016, diketahui bahwa nilai perbandingan jumlah pengadaan dengan konsumsi beras, rasio paling kecil bernilai 0,9 yakni diwilayah kecamatan Jombang Kota. Hal ini mengartikan jumlah konsumsi di wilayah Jombang Kota lebih tinggi dibandingkan jumlah pengadaan beras wilayah tersebut. Selanjutnya rasio perbandingan paling tinggi yakni diwilayah kecamatan Bareng yakni bernilai 5,1. Hal ini berarti jumlah pengadaan beras atau produksi beras 5 kali lebih besar dibandingkan jumlah konsumsi wilayah tersebut. Kemudian secara rata-rata keseluruhan dari 21 kecamatan, diketahui rasio perbandingan sebesar
2,8. Hal ini mengartikan jumlah pengadaan beras (jumlah produksi beras) lebih besar 2,8 kali dibandingkan jumlah konsumsi, jika melihat nilai rata-rata 2,8 kali ini diindikasikan ketersedian beras relatif aman. Hal ini juga disampaikan oleh Badan Ketahanan Pangan (2018) dalam laporan ketahanan pangan bahwa ketersedian pangan apabila memiliki nilai rasio ketersediaan diatas 2 .

Meskipun demikian agar juga diperhatikan nilai simpangan baku disekitar rata-rata yang sebesar 1,16 dimana penyebarannya cukup tinggi. Hal ini mengartikan jumlah pengadaan beras pada kecamatan tidak semuanya lebih besar dari jumlah konsumsi, sehingga masih ada beberapa kecamatan yang mengalami defisit beras karena tingkat konsumsinya lebih besar dari produksinya atau dengan kondisi rasio ketersediaan beras dibawah nilai 2 (BPS Kabupaten Jombang: 2018).

Berikut ini selengkapnya tabel jumlah pengadaan dan konsumsi beras di wilayah kecamatan kabupaten Jombang.

Tabel 3. Rata-rata Jumlah Pengadaan dan Konsumsi Beras di Wilayah Kecamatan Kabupaten Jombang (Kwintal Per Tahun)

\begin{tabular}{|c|l|c|c|}
\hline No & Kecamatan & $\begin{array}{c}\text { Pengadaan } \\
\text { Beras } \\
\text { Kw/th })\end{array}$ & $\begin{array}{c}\text { Konsumsi } \\
\text { Beras } \\
\text { Kw/th) }\end{array}$ \\
\hline 1 & $\begin{array}{l}\text { Bandar } \\
\text { Kedung } \\
\text { Mulyo }\end{array}$ & 131.446 & 39.262 \\
\hline 2 & Bareng & 227.593 & 45.039 \\
\hline 3 & Diwek & 118.026 & 93.292 \\
\hline 4 & Gudo & 172.790 & 45.791 \\
\hline 5 & Jogoroto & 80.873 & 59.369 \\
\hline 6 & $\begin{array}{l}\text { Jombang } \\
\text { Kota }\end{array}$ & 112.694 & 125.167 \\
\hline 7 & Kabuh & 115.086 & 35.329 \\
\hline 8 & Kesamben & 205.148 & 54.686 \\
\hline 9 & Kudu & 50.196 & 25.472 \\
\hline 10 & Megaluh & 144.977 & 33.264 \\
\hline 11 & Mojoagung & 116.228 & 67.714 \\
\hline
\end{tabular}

Lanjutan Tabel 3. Rata-rata Jumlah Pengadaan dan Konsumsi Beras di Wilayah Kecamatan Kabupaten Jombang (Kwintal Per Tahun) 


\begin{tabular}{|c|l|c|c|}
\hline No & Kecamatan & $\begin{array}{c}\text { Pengadaan } \\
\text { Beras } \\
\text { (Kw/th) }\end{array}$ & $\begin{array}{c}\text { Konsumsi } \\
\text { Beras } \\
(\text { Kw/th) }\end{array}$ \\
\hline 12 & Mojowarno & 258.121 & 78.657 \\
\hline 13 & Ngoro & 161.667 & 62.512 \\
\hline 14 & Ngusikan & 47.788 & 19.011 \\
\hline 15 & Perak & 160.278 & 46.577 \\
\hline 16 & Peterongan & 118.165 & 59.284 \\
\hline 17 & Plandaan & 127.201 & 31.801 \\
\hline 18 & Ploso & 102.576 & 35.226 \\
\hline 19 & Sumobito & 173.099 & 71.521 \\
\hline 20 & Tembelang & 171.159 & 45.086 \\
\hline 21 & Wonosalam & 30.518 & 28.159 \\
\hline \multicolumn{2}{|l|}{ Rata-rata } & $\mathbf{1 3 4 . 5 5 4}$ & $\mathbf{5 2 . 4 8 7}$ \\
\hline
\end{tabular}

Sumber: Data BPS Kabupaten Jombang, tahun 2010 $-2016$

Berdasarkan Tabel 3 diatas, dikatahui rata-rata jumlah pengadaan beras sebesar 134.554 kwintal per tahun per kecamatan. Kemudian diketahui rata-rata jumlah konsumsi beras sebesar 52.487 kwintal per tahun per kecamatan.

II. Analisis Biplot

Analisis biplot digunakan bertujuan menganalisis untuk memetakan keragaman, memetakan korelasi dari variabel jumlah konsumsi dan pengadaan beras di wilayah kecamatan kabupaten Jombang. Tujuan selanjutnya memetakan kemiripan karakteristik antara wilayah-wilayah kecamatan, kemudian memetakan posisi keunggulan antar wilayah kecamatankecamatan terkait variabel jumlah konsumsi dan pengadaan beras di kabupaten Jombang.

Berikut ini proses analisis biplot pada variabel jumlah konsumsi dan pengadaan beras diwilayah kecamatan kabupaten Jombang. Seperti yang dilakukan Siswanto, dkk (2016), bahwa perhitungan awal pada analisis biplot berupa eigenvalue dan skor faktor, disampaikan pada Tabel 4 berikut.

Tabel 4. Eigenvalues dan Skor Faktor

\begin{tabular}{|l|}
\hline Eigen analysis of the Correlation Matrix \\
\hline Eigenvalue 1,2980 0,7020 \\
\hline Proportion $0,649 \quad 0,351$ \\
\hline Cumulative $0,649 \quad 1,000$ \\
\hline Variable \\
\hline Pengadaan_Beras
\end{tabular}

Jumlah_Konsumsi_Beras $0,707 \quad 0,707$

Sumber: Hasil analisa biplot (2020)

Berdasarkan nilai eigenvalue diatas, yang bernilai lebih dari 1 yakni 1,30 dengan nilai kumulatifnya sebesar 0,65 . Hal ini mengartikan bahwa dua variabel yang digunakan untuk melihat hubungan diantara variabel adalah mampu menjelaskan sebesar $65 \%$. Artinya informasi yang mampu dijelaskan dengan biplot adalah sudah baik dimana lebih dari 50\%. Sehingga dapat dikatakan bahwa hasil analisis biplot cukup memberikan keragaman informasi mengenai hubungan diatara variabel tersebut.

Selanjutnya berdasarkan skor variabel pengadaan beras pada priciple component 1 (PC1) adalah titik koordinat $\mathrm{X}$, dan priciple component 2 (PC2) adalah titik koordinat Y. Sehingga variabel pengadaan beras memiliki koordinat $(0,707 ;-0,707)$ dan jumlah konsumsi beras memiliki titik koordinat $(0,707 ; 0,707)$.

Kemudian berdasarkan skor nilai tiap obyek kecamatan, juga diketahui titik koordinat dari setiap obyak kecamatan yang menginformasikan posisi dari suatu obyek didalam koordinat dua dimensi (X; Y). Skor nilai titik koordinat tiap obyek kecamatan, selengkapnya sebagai berikut.

Tabel 5. Skor Titik Koordinat Obyek Kemacatan

\begin{tabular}{|l|l|l|}
\hline Kecamatan & Sumbu X & Sumbu Y \\
\hline Bandar K.M & $-0,41$ & $-0,33$ \\
\hline Bareng & 0,94 & $-1,36$ \\
\hline Diwek & 0,94 & 1,35 \\
\hline Gudo & 0,28 & $-0,66$ \\
\hline Jogoroto & $-0,47$ & 0,86 \\
\hline Jombang Kota & 1,78 & 2,32 \\
\hline
\end{tabular}

Lanjutan Tabel 5. Skor Titik Koordinat Obyek Kemacatan

\begin{tabular}{|l|l|l|}
\hline Kecamatan & Sumbu X & Sumbu Y \\
\hline Kabuh & $-0,72$ & $-0,24$ \\
\hline Kesamben & 0,93 & $-0,81$ \\
\hline Kudu & $-1,80$ & 0,28 \\
\hline Megaluh & $-0,41$ & $-0,67$ \\
\hline Mojoagung & 0,20 & 0,65 \\
\hline
\end{tabular}




\begin{tabular}{|l|l|l|}
\hline Mojowarno & 2,26 & $-0,79$ \\
\hline Ngoro & 0,62 & $-0,05$ \\
\hline Ngusikan & $-2,01$ & 0,13 \\
\hline Perak & 0,15 & $-0,48$ \\
\hline Peterongan & $-0,01$ & 0,39 \\
\hline Plandaan & $-0,67$ & $-0,49$ \\
\hline Ploso & $-0,88$ & $-0,09$ \\
\hline Sumobito & 1,01 & 0,06 \\
\hline Tembelang & 0,24 & $-0,66$ \\
\hline Wonosalam & $-1,97$ & 0,60 \\
\hline
\end{tabular}

Sumber: Hasil analisa biplot (2020)

Berdasarkan nilai titik koordinat dari variabel penelitian dan titik koordinat dari obyek penelitian diatas. Selanjutnya dapat dibuat tampilan grafik dua dimensi hasil analisis biplot, sebagai berikut.

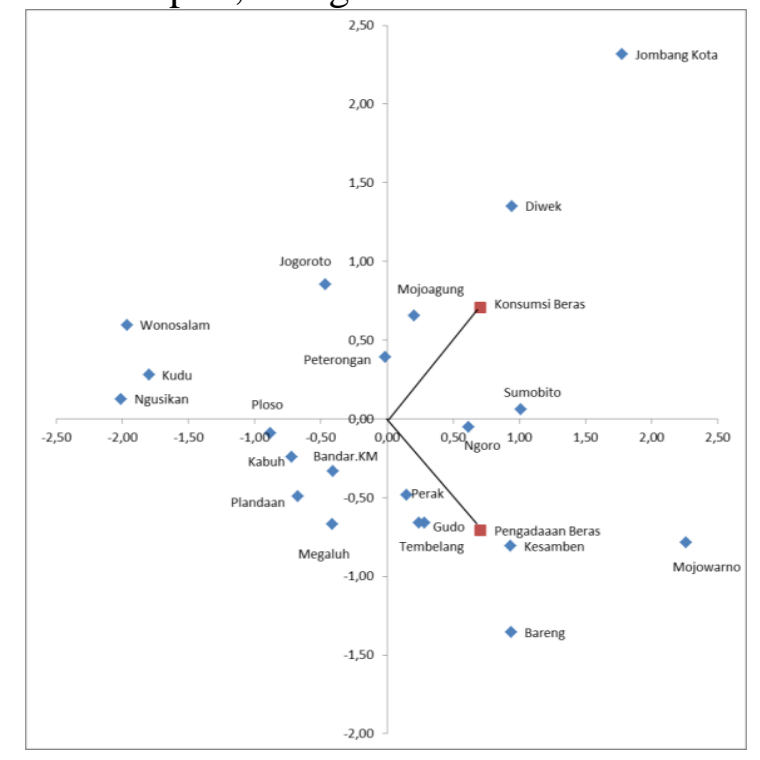

Gambar 3. Tampilan Grafik Analisis Biplot Pengadaan dan Konsumsi Beras di Kecamatan Kabupaten Jombang

Grafik biplot diatas, berisikan titik persegi empat (warna coklat) mewakili unsur variabel konsumsi beras dan variabel pengadaan beras. Kemudian titik diamon (warna biru) mewakili obyek kecamatankecamatan di kabupaten Jombang.

\section{Hasil dan Pembahasan Analisis Biplot}

Analisis pemetaan konsumsi dan pengadaan beras di wilayah kecamatan kabupaten Jombang, diuraikan dari hasil analisis biplot. Hasil analisis biplot berisikan empat analisis pemetaan, uraian hasil analisis pemetaan biplot, selengkapnya disampaikan sebagai berikut.

(1) Analisis pemetaan keragaman dari variabel jumlah konsumsi dan jumlah pengadaan beras.

Berdasarkan panjang pendek dari vektor yang dimiliki oleh variabel konsumsi dan pengadaan beras. Kedua variabel tersebut memiliki vektor dengan panjang yang relatif sama, hal ini berarti nilai keragaman dari keinginan atau kebutuhan variabel jumlah konsumsi beras dengan variabel jumlah pengadaan beras adalah relatif sama.

Nilai keragaman dari variabel tersebut mengartikan bahwa semua kecamatankecamatan di kabupaten Jombang, sudah memiliki kesamaan dalam keinginan dan kebutuhan akan jumlah konsumsi beras dan jumlah pengadaan beras yang sesuai kebutuhan. Hal ini sesuai dengan hasil Susenas 2018, bahwa tingkat pengeluaran konsumsi suatu barang memiliki pola relatif sama dengan tingkat ketersediaan barang tersebut.

(2) Analisis pemetaan korelasi dari variabel jumlah konsumsi dan jumlah pengadaan beras.

Berdasarkan grafik analisis biplot diatas, diketahui tingkat korelasi antara dua faktor yakni dengan melihat sudut arah antara dua vektor. Dua vektor antara konsumsi beras dengan pengadaan beras membentuk sudut dengan besar mendekati $90^{\circ}$, hal ini mengartikan kedua variabel tersebut memiliki korelasi yang tidak erat, yang berarti hubungan pengadaan beras diwilayah kecamatan kabupaten Jombang tidak memiliki hubungan erat dengan jumlah konsumsi beras yang dibutuhkan masyarakat selama 1 tahun. Lebih lanjut hal ini mengartikan bahwa tidak berhubungan erat karena tidak adanya koordinasi antara pihak sumber pengadaan beras dengan pihak yang menangani konsumsi beras. Hal ini juga 
selaras dengan data yang dimiliki BPS Kabupaten Jombang antara tahun 2010 sampai 2016, bahwa rata-rata jumlah pengadaan beras tidak memiliki pola yang linier (berkorelasi) dengan rata-rata jumlah konsumsi.

(3) Analisis pemetaan kemiripan karakteristik antar kecamatan

Berdasarkan grafik biplot diatas, dikatahui titik-titik dari obyek kecamatan yang saling berdekatan posisinya, hal ini menunjukkan kecamatan-kecamatan tersebut memiliki kemiripan karakteristik. Berdasarkan kemiripan dan tidak kemiripan karakteristik tersebut, akan digunakan sebagai pengelompokan kecamatan.

Berikut ini visual pengelopokan hasil pemetaan kemiripan karakteristik.

Tabel 6. Pengelompokan Kemiripan Karakteristik Antar Kecamatan

\begin{tabular}{|l|l|}
\hline No. & Kelompok kemiripan obyek \\
\hline 1. & Wonosalam; Kudu; Ngusikan \\
\hline 2. & $\begin{array}{l}\text { Ploso; Kabuh; Plandaan; Bandar } \\
\text { kedungmulyo; Megaluh }\end{array}$ \\
\hline 3. & $\begin{array}{l}\text { Mojowarno; Bareng; Kesamben; } \\
\text { Tembelang; Gudo; Perak }\end{array}$ \\
\hline 4. & Ngoro; Sumobito \\
\hline 5. & Jombang Kota; Diwek; Mojoagung \\
\hline 6. & Jogoroto; Peterongan \\
\hline
\end{tabular}

Sumber: Hasil analisis biplot (2020)

Ilustrasi gambarnya sebagai berikut:

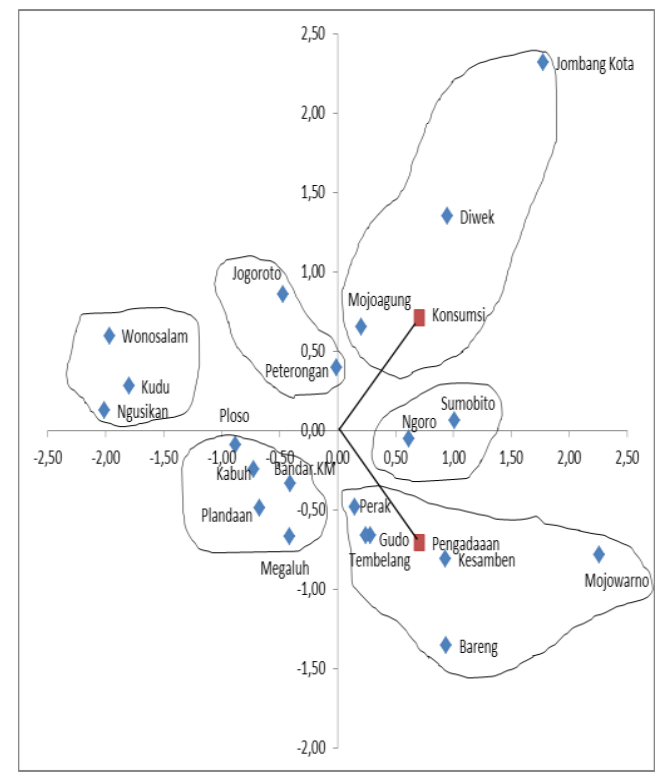

\section{Gambar 4. Kelompok Kemiripan Karakteristik} Antar Kecamatan

Berdasarkan Tabel 6 dan Gambar 4 kemiripan karakteristik kecamatan diatas, dapat ditentukan kelompok kecamatan yang memiliki posisi relatif berdekatan, ditentukan ada 6 kelompok kecamatan yang relatif sama yakni kelompok-1 meliputi kecamatan Wonosalam; Kudu; Ngusikan. Kelompok-2 meliputi kecamatan Ploso; Kabuh; Plandaan; Bandar kedungmulyo; Megaluh. Kelompok-3 meliputi kecamatan Mojowarno; Bareng; Kesamben; Tembelang; Gudo; Perak. Kelompok-4 meliputi kecamatan Ngoro; Sumobito, kemudian kelompok-5 meliputi kecamatan Jombang Kota; Diwek; Mojoagung. Kelompok-6 meliputi kecamatan Jogoroto; Peterongan.

Enam kelompok kecamatan tersebut memiliki kemiripan karakteristik terkait jumlah konsumsi dan pengadaan beras. Hal ini selaras dengan hasil penelitian Afrianto (2010), bahwa pengaruh konsumsi beras dan stok pengadaan beras pada suatu wilayah akan berpengaruh membentuk karakteristik yang sama dari wilayah tersebut, khususnya terkait ketahanan pangan. Selanjutnya dengan pengelompokan wilayah kecamatan ini, akan mempermudah penanganan masalah ketersedian beras diwilayah kecamatan yang memang membutuhkan prioritas penanganan karena kekurangan beras, dan sebaliknya yang kelebihan beras bisa menjadi sumber pemasok.

(4) Analisis pemetaan posisi keunggulan

antar kecamatan

Berdasarkan hasil analisis pemetaan posisi dari grafik biplot, diketahui posisi keunggulan suatu kecamatan jika memiliki posisi terletak searah dengan arah vektor suatu variabel, selanjutnya kecamatan tersebut diartikan memiliki nilai diatas ratarata. Sehingga sebaliknya jika berlawanan dengan arah vektor variabel maka diartikan memiliki nilai dibawah rata-rata. Kemudian apabila posisi suatu kecamatan berada disekitar tengah-tengah dari arah vektor suatu variabel, maka diartikan kecamatan 
tersebut memiliki nilai yang dekat dengan rata-rata. Berikut tabel ilustrasi pemetaan posisi keunggulan antar kecamatan.

Tabel 7. Hasil Pemetaan Posisi Keunggulan Antar Kecamatan Ditinjau Dari Variabel Konsumsi Beras

\begin{tabular}{|c|c|c|}
\hline \multicolumn{3}{|c|}{$\begin{array}{l}\text { Posisi keunggulan kecamatan ditinjau dari } \\
\text { variabel konsumsi beras } \\
\end{array}$} \\
\hline $\begin{array}{c}\text { Diatas rata- } \\
\text { rata }\end{array}$ & $\begin{array}{l}\text { Dekat rata- } \\
\text { rata }\end{array}$ & $\begin{array}{c}\text { Dibawah rata- } \\
\text { rata }\end{array}$ \\
\hline $\begin{array}{l}\text { Jombang kota; } \\
\text { Diwek; } \\
\text { Mojowarno; } \\
\text { Sumobito; } \\
\text { Mojoagung; } \\
\text { Ngoro }\end{array}$ & $\begin{array}{l}\text { Jogoroto; } \\
\text { Peterongan; } \\
\text { Perak; Gudo; } \\
\text { Tembelang; } \\
\text { Kesamben; } \\
\text { Bareng }\end{array}$ & $\begin{array}{l}\text { Wonosalam; } \\
\text { Kudu; } \\
\text { Ngusikan; } \\
\text { Ploso; Kabuh; } \\
\text { Bandar } \\
\text { kedung } \\
\text { mulyo; } \\
\text { Plandaan; } \\
\text { Megaluh }\end{array}$ \\
\hline
\end{tabular}

Sumber: Hasil analisis biplot (2020)

Ilustrasi gambarnya sebagai berikut:

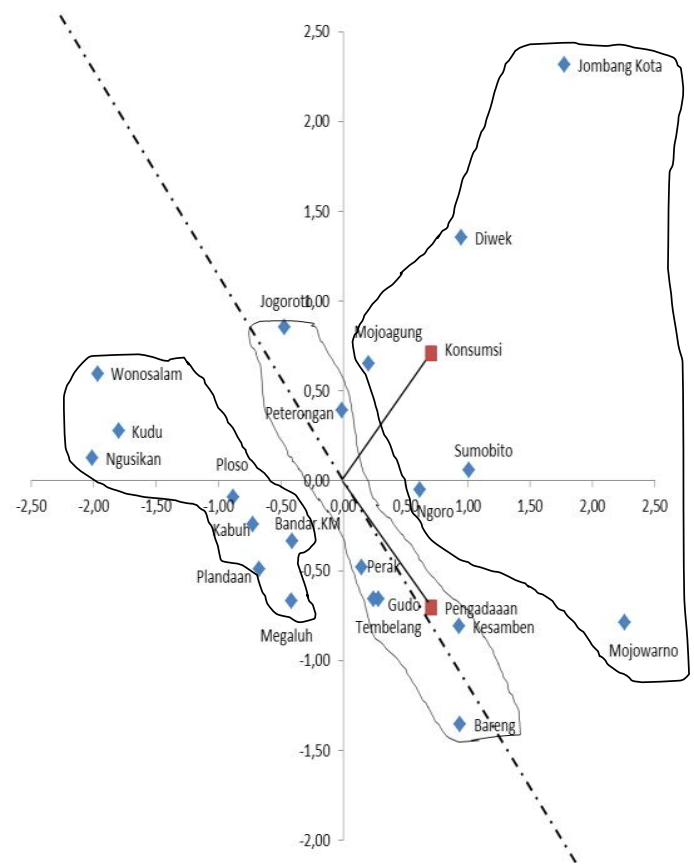

Gambar 5. Posisi keunggulan antar kecamatan ditinjau dari variabel konsumsi beras

Berdasarkan table 7 dan gambar 5 diatas, bahwa posisi keunggulan kecamatan ditinjau dari faktor konsumsi beras, diketahui kecamatan-kacamatan yang memiliki posisi searah yang berarti memiliki nilai jumlah konsumsi beras yang diatas rata-rata, yakni kecamatan Jombang kota; Diwek; Mojowarno; Sumobito; Mojoagung;
Ngoro. Kemudian kecamatan dengan nilai disekitar rata-rata yakni Jogoroto; Peterongan; Perak; Gudo; Tembelang; Kesamben; Bareng. Sedangkan kecamatan dengan nilai dibawah rata-rata yakni Wonosalam; Kudu; Ngusikan; Ploso; Kabuh; Bandar kedung mulyo; Plandaan; Megaluh. Hal ini selaras dengan data BPS Kabupaten Jombang terkait rata-rata konsumsi beras per kecamatan tahun 2010 2016 yakni sebesar 52.487 kwintal per tahun, bahwa kecamatan yang konsumsi diatas rata-rata seperti kecamatan kota, diwek, sumobito, mojoagung, ngoro, mojowarno memiliki nilai konsumsi diatas rata-rata tersebut diatas. Begitu juga untuk kelompok kecamatan yang dekat rata-rata. Kemudian dibawah rata-rata memiliki nilai konsumsi yang lebih rendah dibanding ratarata konsumsi beras tiap kecamatan di Jombang.

Tabel 8. Hasil Pemetaan Posisi Keunggulan Antar Kecamatan Ditinjau Dari Variabel Pengadaan Beras

\begin{tabular}{|l|l|l|}
\hline \multicolumn{3}{|c|}{$\begin{array}{c}\text { Posisi keunggulan kecamatan ditinjau dari variabel } \\
\text { pengadaan beras }\end{array}$} \\
\hline $\begin{array}{c}\text { Diatas rata- } \\
\text { rata }\end{array}$ & \multicolumn{1}{|c|}{ Dekat rata-rata } & $\begin{array}{c}\text { Dibawah rata- } \\
\text { rata }\end{array}$ \\
\hline Bareng; & Bandar & Wonosalam; \\
Mojowarno; & kedungmulyo; & Kudu; \\
Kesamben; & Plandaan; & Ngusikan; \\
Gudo; & Kabuh; & Ploso; \\
Tembelang; & Megaluh; & Jogoroto; \\
Perak & Peterongan; & Diwek; \\
Sumobito; & Mojoagung & Jombang kota \\
Ngoro & & \\
\hline
\end{tabular}

Sumber: Hasil analisis biplot (2020) 
Ilustrasi gambarnya sebagai berikut:

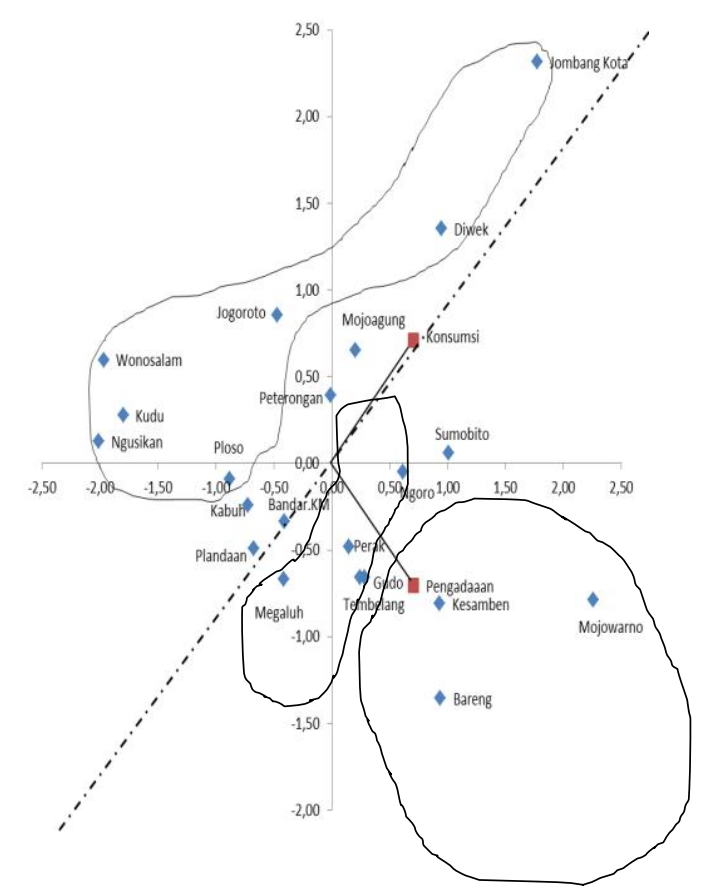

Gambar 6. Posisi Keunggulan Antar Kecamatan Ditinjau dari Variabel Pengadaan Beras

Berdasarkan tabel 8 dan gambar 6 diatas, bahwa posisi keunggulan kecamatan ditinjau dari faktor pengadaan beras, diketahui kecamatan-kacamatan yang memiliki posisi searah yang berarti memiliki nilai jumlah pengadaan beras yang diatas rata-rata, yakni kecamatan Bareng; Mojowarno; Kesamben; Gudo; Tembelang; Perak Sumobito; Ngoro. Kemudian kecamatan dengan nilai disekitar rata-rata yakni Bandar kedungmulyo; Plandaan; Kabuh; Megaluh; Peterongan; Mojoagung. Sedangkan kecamatan dengan nilai dibawah rata-rata yakni Wonosalam; Kudu; Ngusikan; Ploso; Jogoroto; Diwek; Jombang kota. Hal ini selaras dengan data BPS Kabupaten Jombang terkait rata-rata pengadaan beras per kecamatan tahun 2010 - 2016 yakni sebesar 134.554 kwintal per tahun, bahwa diketahui kecamatan yang pengadaan nya diatas rata-rata seperti kecamatan Bareng; Mojowarno; Kesamben; Gudo; Tembelang; Perak Sumobito; Ngoro memiliki nilai pengadaan diatas rata-rata tersebut diatas. Begitu juga untuk kelompok kecamatan yang dekat rata-rata. Kemudian dibawah rata-rata juga memiliki nilai pengadaan beras yang lebih rendah dibanding rata-rata pengadaan beras tiap kecamatan di Jombang.

\section{Simpulan}

Analisis pemetaan jumlah konsumsi dan pengadaan beras di kecamatan kabupaten Jombang, disimpulkan tingkat keragaman jumlah konsumsi dan pengadaan beras adalah relatif sama. Implikasi dari hasil ini bahwa diantara 21 kecamatan di kabupaten Jombang, memiliki kesamaan dalam keinginan kebutuhan akan konsumsi dan pengadaan beras. Sehingga dengan pemahaman ini, diketahui semua kecamatan di kabupaten Jombang sudah memiliki keinginan, kebutuhan akan konsumsi dan pengadaan beras. Oleh karenanya perlu ditindaklanjuti dengan kebijakan pemerintah untuk melakukan stimulasi pemenuhan jumlah konsumsi dan menjaga serta meningkatkan usaha pengadaan beras di semua wilayah kecamatan.

Selanjutnya hasil analisis pemetaan korelasi antara variabel jumlah konsumsi dengan pengadaan beras adalah tidak erat berkorelasi. Implikasi dari hasil ini bahwa nilai dari jumlah konsumsi beras masyarakat, tidak terbentuk atau tidak memiliki keterkaitan erat dengan nilai jumlah pengadaan beras. Sehingga dengan pemahaman ini, diketahui tidak ada koordinasi antara pihak-pihak terkait konsumsi dengan pihak-pihak pengadaan beras, tidak adanya koordinasi berdampak pada tidak efisien rantai pasok. Oleh karenanya diperlukan kebijakan menata koordinasi pihak terkait konsumsi beras dengan pihak pengadaan beras.

Hasil analisis pemetaan karakteristik antar kecamatan, disimpulkan terdapat 6 kelompok kecamatan yang memiliki kesamaan terkait variabel konsumsi dan pengadaan beras. Implikasi dari hasil ini, yakni pengelompokan tersebut memberikan gambaran yang jelas terkait wilayah yang sama dan berbeda. Dengan demikian bisa memberi acuan program kebijakan terkait 
target penanganan kecamatan yang lebih tepat untuk masing-masing kelompok untuk variabel konsumsi dan pengadaan beras.

Hasil analisis pemetaan posisi keunggulan kecamatan, disimpulkan terdapat kelompok kecamatan yang unggul diatas rata-rata, kelompok disekitar rata-rata, dan kelompok dibawah rata-rata dalam jumlah konsumsi dan pengadaan beras. Implikasi dari hasil ini bahwa diketahui terdapat kekurangan dan kelebihan wilayah kecamatan terkait jumlah konsumsi dan pengadaan beras. Sehingga dari informasi tersebut akan memberikan masukan terkait skala prioritas program ketersediaan beras, dan program pemenuhan konsumsi beras yang disesuaikan dengan posisi keunggulan masing-masing kecamatan.

\section{Daftar Pustaka}

Arsyad M. (2018). Dilema pangan Beras di Indonesia: Paradoks tambah produksi atau kurangi konsumsi. Prosiding Seminar Nasional Ekonomi Konsumsi Pangan dan Pertanian; 2018 Nov 21; Surakarta; Indonesia. Perhimpunan Ekonomi Pertanian Indonesia (PERHEPI) Komisariat Daerah Surakarta.

Afrianto D. (2010). Analisis Pengaruh Stok

Beras, Luas Panen, RataRata Produksi, Harga Beras, dan Jumlah Konsumsi Beras Terhadap Ketahanan Pangan di Jawa Tengah. Universitas Diponegoro Semarang.

Badan Pusat Statistik [BPS]. (2018). Kabupaten Jombang Dalam Angka 2017. Data publikasi BPS Kabupaten Jombang

Badan Pusat Statistik [BPS] (2018). Pengeluraran untuk Konsumsi Penduduk Indonesua: Hasil Susenas Maret 2018.

Badan Kependudukan Keluarga Berencana Nasionak [BKKBN]. (2018). Waspadai Ledakan Penduduk. Jurnal Keluarga:Edisi keempat 2018: 4-11.
Ghozali, I. (2018). Aplikasi Analisis Multivariate dengan Program IBM SPSS 25. Badan Penerbit Universitas Diponegoro: Semarang

Https://jombangkab.bps.go.id/statictable/20 17/08/01/164/ jumlah-pendudukmenurut-kabupaten- jombang-diindonesia -orang -2012- 2016. html

Kementerian Pertanian (2016). Outlook Komoditas Pertanian Sub Sektor Tanaman Pangan Padi. Pusat Data dan Sistem Informasi Pertanian Kementerian Pertanian.

Lastinawati, E (2010). Diversifikasi Pangan dalam Mencapai Ketahanan Pangan. AgronobiS, Vol. 2, No. 4, September 2010. Prodi Agribisnis Fakultas Pertanian Universitas Baturaja

Mattjik, A.A, dkk (2011). Sidik Peubah Ganda. Departemen Statistika, Institut Pertanian Bogor.

Rukini (2017). Analisis Perubahan Kelompok Berdasarkan Indikator Kesejahteraan Rakyat tahun 20102015 di Propinsi 2010-2015. Prosiding Konferensi Nasional Penelitian dan Pembelajarannya II. UMS.

Siswanto, dkk (2016), Analisis Peubah Ganda, Pasca sarjana Institut Pertanian Bogor. 